\title{
Bełchatów 2030: alternatywne scenariusze transformacji
}

\author{
Bełchatów 2030: \\ The Altenative Scenarios of the Transformation
}

\section{Paweł Ruszkowski}

Collegium Civitas, Warszawa, Polska

mail: pawel.witold.ruszkowski@gmail.com

ORCID: 0000-0001-5015-7178

Abstract

The article presents strategic dilemmas of the Bełchatów mining and energy complex. The coal lobby aims to continue the conventional profile by launching a new open pit in Złoczew, and experts from environmental organizations propose to enter the green investment trend. A responsible strategy for the survival of the Bełchatów energy complex as an employer must assume alternative scenarios.

Keywords - Betchatón, transformation, strategic dilemmas, mining and energy complex, Z toczen, green investments, renewable energy sources, decarbonisation 


\section{Energetyka wobec transformacyjnej presji}

Ograniczenie aktywności gospodarczej, jakie występuje na skutek epidemii COVID-19, wpłynęło negatywnie na poziom wzrostu gospodarczego w całej Unii Europejskiej (UE) w roku 2020. Należy spodziewać się, że systemowe skutki kryzysu będą odczuwalne przez gospodarkę europejską również w latach następnych. Stąd nadzwyczajne programy ratunkowe, jak przyjęty właśnie przez UE fundusz odbudowy o wartości 1,8 bln euro.

W Polsce od wielu lat mamy do czynienia z kryzysem energetycznym, wynikającym z polityki państwa, preferującej rozwój konwencjonalnych źródeł energii oraz hamującej rozwój odnawialnych źródeł energii. W efekcie przeprowadzenia konsolidacji pionowej firm elektroenergetycznych powstała monopolistyczna struktura organizacyjno-własnościowa elektroenergetyki, podlegająca biurokratycznej kontroli ze strony centrum politycznego (rządu). Polityka inwestycyjna w sektorze elektroenergetycznym, realizowana przez państwowe koncerny energetyczne, wzmocniła pozycję energetyki węglowej, co spowodowało obniżenie poziomu innowacyjności technicznej i technologicznej całego sektora oraz wzrost ryzyka kosztów osieroconych.

W końcu stycznia 2021 roku rząd przyjął Polityke Energetyczna Polski do 2040 r. (dalej jako PEP 2024). Szacuje się, że w latach 2021-2040 skala nakładów inwestycyjnych w obszarze energetyki może sięgnąc 1600 mld złotych. Do roku 2030 na krajową transformację energetyczno-klimatyczną skierowanych zostanie $260 \mathrm{mld}$ zł ze środków unijnych i krajowych [1, s. 3-4].

W sensie strategicznym jest to kolejna próba znalezienia kompromisu pomiędzy wymogami Zielonego Ładu, a oczekiwaniami środowisk społecznych związanych z energetyką konwencjonalna. Rząd deklaruje, że udział węgla w miksie energetycznym zostanie zmniejszony do 11\% w roku 2040, równocześnie wskazuje, że w roku 2030 udział węgla w wytwarzaniu energii elektrycznej wyniesie 56\%, zaś udział odnawialnych źródeł energii (OZE) - 23\%. Taki plan transformacji energetyki może uchronić rząd przed wizyta dziesięciu tysięcy górników w centrum Warszawy, trudno jednak oczekiwać aplauzu ze strony Komisji Europejskiej.

Ważnym i zarazem mocno kontrowersyjnym elementem rządowej strategii jest energetyki węglowej przez elektrownie jądrowe oraz przez morską energetykę wiatrowa. Czynnikiem uzupełniającym bilans energetyczny w okresie przejściowym mają być 
źródła gazowe. Wątpliwości dotyczą kapitałochłonnej oraz czasochłonnej inwestycji w energetykę jądrową oraz dążenia do dominacji państwowych spółek energetycznych na rynkach związanych z OZE.

W kręgach decyzyjnych krążą opinie wskazujące na dążenie do maksymalnego zaangażowania środków unijnych w proces realizacji projektów zgłaszanych przez państwowe spółki energetyczne. W zasadzie przyjmuje się, że całość tych środków powinna zostać zaangażowana w inwestycje państwowych koncernów energetycznych. Projekty propagujące rozwój elektroprosumeryzmu, lokalnych i regionalnych systemów energetyki rozproszonej, traktowane są jako biznesowo konkurencyjne. Mechanizmy biurokratyczne, które odgrywają istotną rolę w przygotowaniu i ewaluacji tych projektów, będa sprzyjać projektom koncernów energetycznych, zwłaszcza, że będą to inwestycje o dużym potencjale finansowym.

W praktyce może się okazać, że Fundusz Sprawiedliwej Transformacji stanie się wehikułem finansowym, umożliwiającym przejęcie „zielonej transformacji” przez państwowe spółki energetyczne. Pozwoli to na utrzymania ich monopolistycznej pozycji na tradycyjnie rozumianym rynku energii oraz przyczyni się do hamowania ekspansji małych i średnich firm prywatnych w obszarze wytwarzania energii elektrycznej, rynku usług elektrycznych i rynku urządzeń elektrycznych. W efekcie głęboka transformacja energetyczna oparta na szerokim wprowadzeniu elektroprosumeryzmu oraz systemów energetyki rozproszonej może przesunąć się nawet o dekadę.

Do tej pory głównym czynnikiem trwania państwowych spółek energetycznych była gotowość Polaków do płacenia rachunków za ich zacofanie technologiczne, organizacyjne i zarządcze. Ten stan fałszywej świadomości społecznej stopniowo odchodzi w przeszłość. W przypadku młodych Polaków mamy do czynienia z pokoleniowym buntem klimatycznym. Wkrótce szersze kręgi społeczne dostrzega fakt, że wbrew swojej woli ponoszą koszty dominującej pozycji energetyki państwowej w polskiej gospodarce. W końcu jednak rosnące ceny energii elektrycznej uruchomia mechanizmy społecznego niezadowoleni i społecznego oporu. Wiele wskazuje na to, że ta zmiana świadomościowa dokona się jeszcze przed kolejnymi wyborami parlamentarnymi, planowanymi na jesień 2023 roku. 


\section{Bełchatów - strategia kontynuacji}

Dylematy strategiczne, których nie rozwiązuje PEP 2040, można prześledzić na przykładzie kompleksu górniczo-energetycznego Bełchatów. Odnośnie tego miejsca minister Piotr Naimski obiecuje lokalizację elektrowni atomowej, lobby węglowe dąży do kontynuacji profilu konwencjonalnego przez uruchomienie nowej odkrywki w Złoczewie, zaś eksperci organizacji ekologicznych proponują wejście w nurt zielonych inwestycji.

Bełchatów można potraktować jako przykład modelowego konfliktu interesów, jaki rozegra się w skali makro. Z jednej strony do gry wchodzi silny koncern państwowy o tradycyjnej technologii i stylu zarządzania, zatrudniający ok. 10 tys. pracowników (plus 3-4 tys. w bezpośrednim otoczeniu). Z drugiej strony - środowisko biznesowe Bełchatowa to kilkanaście tysięcy drobnych przedsiębiorców i kilkaset firm średniej wielkości, działających w różnych segmentach produkcji i usług.

Głównym pomysłem na utrzymanie produkcji energii elektrycznej w Elektrowni Bełchatów jest budowa kopalni odkrywkowej węgla brunatnego w odległym o $50 \mathrm{~km}$ Złoczewie. Największą słabością tej koncepcji jest wysoki koszt inwestycji-ok. $15 \mathrm{mld}$ zł. Dodatkowy koszt to budowa linii kolejowej do transportu węgla za ok. $900 \mathrm{mln}$ zł. W świetle opinii ekspertów uzyskanie finansowania dla tego przedsięwzięcia jest mało prawdopodobne. Michał Wilczyński wskazuje następujące zagrożenia opłacalności tego projektu: pokłady węgla leżą $354 \mathrm{~m}$ poniżej powierzchni terenu; ich eksploatacja wymaga zastosowania materiałów wybuchowych; okoliczne obszary będą miały bardzo poważny problem z dostępem do wody; budowa odkrywki wymaga wysiedlenia 3000 mieszkańców z 33 miejscowości [2, s. 11-12].

Według ekspertyzy Benedykta Pelplińskiego, $450 \mathrm{mln}$ ton węgla w złożu Złoczew warte jest od 33,8 do 45,1 mld zł, co oznacza, że rentowność spalenia w elektrowniach wydobytego węgla powinna wynosić ponad 7,7-10,3\%, jeśli uwzględni się tylko formalny obszar leja depresji. W najbardziej realnym scenariuszu kosztów zewnętrznych, rentowność spalenia w elektrowniach wydobytego węgla powinna wynosić 29,8-39,7\%. Tymczasem w latach 2009-2017 średnia rentowność uzyskiwana przez PGE wynosiła $10,5 \%[3$, s. 5-6].

Z analiz Rady Powiatu wynika, że wyczerpywanie się złóż węgla brunatnego spowoduje stopniowy spadek zatrudnienia, nawet w przypadku uruchomienia odkrywki 
w Złoczewie. W ostatnich latach w Kopalni Węgla Brunatnego Bełchatów wydobywa się rocznie około $40 \mathrm{mln}$ ton węgla brunatnego. Zasoby odkrywki „Szczerców” wynoszą wprawdzie 650 mln ton, przewiduje się jednak, że główny strumień zbieranego nadkładu z tej odkrywki zostanie wyczerpany najpóźniej do roku 2028. Spowoduje to likwidację większości ciągów nadkładowych oraz związaną z tym redukcję zatrudnienia. Dlatego oczekuje się, że w okresie najbliższych 2-3 lat poziom zatrudnienia w bełchatowskim kompleksie górniczo-energetycznym będzie obniżał się o około 500 osób rocznie, a w perspektywie lat 2028-2032 nastapi kumulacja tego procesu. W praktyce oznacza to, że uzyskane w optymalnym wariancie 1500 miejsc pracy w Złoczewie nie gwarantuje przetrwania społeczności zakładowej, w jej dotychczasowym kształcie.

Przeprowadzona analiza wyraźnie wskazuje, że głównym elementem ryzyka inwestycyjnego, w przypadku odkrywki „Złoczew” jest niskie prawdopodobieństwo zwrotu zainwestowanego kapitału. W praktyce wyklucza to realną możliwość pozyskania środków na sfinansowanie tego przedsięwzięcia.

Moim zdaniem, zarówno pracownicy, jak też reprezentujący ich interesy związkowcy, powinni uwzględnić w swoim planie ratunkowym argument, że odkrywka „Złoczew” jest przedsięwzięciem o dużym współczynniku ryzyka ekonomicznego i politycznego. Trzymanie się „strategii kontynuacji” oznacza traktowanie kompleksu przemysłowego Bełchatów jako centralnego zasobu energetyki konwencjonalnej. Załamanie się tego kierunku inwestycji energetycznych może w przypadku Bełchatowa skutkować efektem PGR-ów z lat 90. zeszłego wieku. Po raz kolejny może okazać się, że gry prowadzone przez grupy interesów węgla kamiennego są bliższe dążeniom elit politycznych, niż interesy energetyki węgla brunatnego. W kontekście powyższych uwarunkowań uważam, że odpowiedzialna strategia przetrwania kompleksu energetycznego Bełchatów jako pracodawcy musi zakładać scenariusze alternatywne.

\section{Bełchatów - strategia konwersji kapitałów}

Zwróćmy uwage, że w gospodarce post pandemicznej walka konkurencyjna o pozyskanie kapitału inwestycyjnego będzie znacznie ostrzejsza, niż w okresie minionych pięciu lat. Wystąpi duże zróżnicowanie sytuacji branż i regionów. W tej grze, która już się rozpoczęła, istotne znaczenie odegrają zasoby różnego typu kapitałów będących w posiadaniu poszczególnych środowisk. Chodzi tu przede wszystkim o zasoby kapitału 
ludzkiego, społecznego, finansowego i politycznego. W sytuacji kryzysowej, gdy zasoby są zawsze niewystarczające, warto pomyśleć o łączeniu kapitałów i ich konwersji, o budowaniu strategii przetrwania Bełchatowa jako społeczności lokalnej, w której elektrownia i kopalnia są ważnym, ale nie jedynym liczącym się środowiskiem społecznym.

W ocenie społecznego potencjału Bełchatowa nie można lekceważyć wyraźnej tendencji do zmniejszania się liczby mieszkańców. W roku 1975 miasto zamieszkiwało ok. 10 tys. osób. Szczytowy poziom napływu ludności to rok 2002, kiedy w Bełchatowie mieszkało ok. 63 tys. osób. Od kilku lat miasto traci atrakcyjność: w roku 2017 liczba mieszkańców spadła do ok. 58 tys. (dane Rady Powiatu).

Moim zdaniem należy tworzyć wielowariantowe scenariusze przyszłości Bełchatowa, zamiast koncentrować sił i środki na jednym, dużym projekcie. Zdaję sobie sprawę, że w oparciu o wieloletnie doświadczenia liderzy związkowi wierzą w swoje możliwości sprawcze. Oczywiste jest, że żaden decydent nie powie im: „likwidujemy Elektrownię Bełchatów”. Decydenci powiedzą raczej: „Drodzy związkowcy, zaufajcie nam ...”.

Zasoby, którymi dysponuje Bełchatów jako społeczność lokalna, mogą stać się przesłanką budowania efektywnych scenariuszy przyszłości pod warunkiem integracji środowiska energetycznego ze środowiskiem biznesowym. Miasto położone jest w środku Polski, posiada dobre połączenia komunikacyjne z innymi regionami. Silną stroną Bełchatowa sa zasoby ludzkie: kadra kierownicza w elektrowni i kopalni to kilkuset wysoko wykwalifikowanych menadżerów; znacząca grupa inżynierów energetyków dysponuje wysokimi kwalifikacjami zawodowymi, z odpowiednimi uprawnieniami i certyfikatami. Ze strony biznesowej zauważamy obecność na lokalnym rynku kilkuset małych i średnich firm, w tym kilkadziesiąt o ustalonej pozycji i renomie na rynku.

Kryzys energetyki konwencjonalnej w połączeniu zahamowaniem wzrostu gospodarczego w wyniku pandemii można potraktować jako szansę na przebudowę lokalnego systemu interesów. Wymaga to odważnej decyzji, dotyczącej przejścia od kultury energetyki węglowej do kultury opartej na energii odnawialnej. Można wskazać wiele projektów z tego obszaru, które mają szanse na uzyskanie finansowania z funduszy UE.

Punktem wyjścia dla konstruowania nowej formuły biznesowej dla Bełchatowa sa zasoby infrastruktury technicznej, w szczególności zaś elektroenergetycznej. Kluczowe znaczenie maja dwie duże elektroenergetyczne stacje przesyłowe, pozwalające na realizację projektów przyłączeniowych instalacji OZE w skali całego regionu. Jak wiadomo, możliwości przyłączeniowe są w polskim systemie elektroenergetycznym jedną 
z głównych barier rozwojowych energetyki odnawialnej. W oparciu o istniejące zaplecze infrastrukturalne możliwa jest budowa konkurencyjnych farm fotowoltaicznych i wiatrowych, wykorzystujących niskie koszty przyłączenia.

Zasoby kapitału ludzkiego, obejmującego inżynierów i menadżerów energetyków, należy wykorzystać do tworzenia firm usługowych i produkcyjnych związanych z fotowoltaiką i funkcjonowaniem farm wiatrowych. Połączenie istniejących zasobów ludzkich oraz infrastrukturalnych otwiera nowe możliwości inwestycyjne, w postaci generacji hybrydowych (farmy wiatrowe + elektrownie PV + magazyny energii). Taki kierunek rozwoju biznesowego pozwala na rozszerzenie pola działania o produkcję elementów wiatrakowych, paneli słonecznych i baterii dla magazynów energii. We wszystkich tych przedsięwzięciach inwestorami może być biznes prywatny, współpracujący z jednostkami samorządu terytorialnego oraz ze spółkami pracowniczymi, tworzonymi przez pracowników i kadrę elektrowni i kopalni.

Aktualne analizy tendencji rozwojowych w segmencie OZE wskazują na dużą dynamikę produkcji i usług w obszarze fotowoltaiki. Z szacunków Instytutu Energetyki Odnawialnej wynika, że w 2019 roku we wszystkich sektorach PV zatrudnionych było blisko 6 tys. osób, zaś do roku 2025 we wszystkich branżach w fotowoltaice zatrudnienie może znaleźć blisko 16 tys. osób [4, s. 7].

W tworzeniu konkurencyjnych scenariuszy transformacji Bełchatowa warto mieć na uwadze fakt, że Komisja Europejska widzi w zielonej energetyce ważny składnik europejskich działań antykryzysowych. Sytuacja pandemii uzmysłowiła rządom europejskim, że dla zachowania niezależności technologicznej i bezpieczeństwa dostaw (w tym bezpieczeństwa energetycznego) należy w UE produkować nie tylko moduły fotowoltaiczne, lecz także półprodukty (tzw. wafle) i ogniwa stosowane w modułach PV.

Koncepcja uruchomienia w Polsce produkcji płytek, ogniw i modułów (tzw. GigaFactory) już jest w fazie realizacji (Katowice). Celowe jest również wpisanie polskich inwestycji w szersze ramy polityki UE, jako tzw. Projektu Wspólnego Interesu (PCI). Przyjęcie takiego rozwiązania zapewni tym inwestycjom dodatkowe wsparcie w zakresie budowy przewagi konkurencyjnej na rynku [5].

Drugi nurt projektów związanych z zieloną energią to cała gama produktów i usług oferowanych prosumentom. Warunkiem wstępnym ich realizacji jest popularyzacja idei prosumeryzmu w szeroko rozumianym środowisku mieszkańców. Celem projektu jest budowa lokalnego systemu wytwarzania i dystrybucji energii elektrycznej w oparciu 
o OZE. Proces tworzenia tego systemu oraz obsługa jego funkcjonowania w przyszłości - to kolejne miejsca pracy. Warto podkreślić dodatkowy walor systemowy tego projektu: elektroprosumeryzm może stać się płaszczyzną praktycznej współpracy pomiędzy biznesem, władzami samorządowymi a mieszkańcami. Różne formy współdziałania w zakresie zaspokajania potrzeb energetycznych mieszkańców mogą rozpocząć proces budowania nowego typu lokalnej wspólnoty.

Kolejny scenariusz transformacji Bełchatowa nawiązuje do priorytetowego pomysłu rządu, jakim jest elektromobilność. Warto rozważyć projekt produkcji podzespołów do samochodów elektrycznych w Bełchatowie. W zależności od skali inwestycji, dzięki temu może tu powstać kilkaset nowych miejsc pracy. Trzeba jednak mieć świadomość, że gra o pozyskanie tych miejsc pracy toczy się już od pewnego czasu. Wydaje się jednak, że w tym kontekście istotną rolę może odegrać kapitał polityczny, jakim wciąż jeszcze dysponują związki zawodowe.

Trzeci scenariusz wprowadza element dywersyfikacji oferty biznesowej poprzez utworzenie firmy produkcyjnej, średniej wielkości, np. w branży przemysłu elektrotechnicznego i elektronicznego (maszyny elektryczne, silniki elektryczne, transformatory, akumulatory). Można tu uwzględnić projekt własności mieszanej, łączącej kapitał prywatny i samorządowy. Argumentem na rzecz lokalizacji tego typu inwestycji w Bełchatowie jest podaż wysoko wykwalifikowanej siły roboczej.

\section{Elektrownia Bełchatów jako społeczność zakładowa}

Dla konstruowania strategii przyszłości Bełchatowa ważne znaczenie ma precyzyjne określenie typu kapitału społecznego, który powoduje, że mówimy o załogach elektrowni czy kopalni jako o zintegrowanych środowiskach społecznych, dysponujacych pewną siła polityczna, zdolnych do wywierania wpływu na otoczenie instytucjonalne. Kapitał społeczny jest tu rozumiany jako typ więzi łączącej pracowników najemnych w społeczność zakładowa, mająca swoich liderów, zespół norm regulujących ich wzajemne stosunki oraz system podzielanych wartości. Zaprezentowana poniżej charakterystyka społeczności zakładowej Elektrowni Bełchatów opiera się na wynikach badań środowisk przemysłowych [6], przeprowadzonych w latach 2007-2009 w następujących 
firmach: Kopalnia Węgla Brunatnego Turów S.A.; Elektrownia Turów S.A.; Elektrownia Opole S.A.; Elektrownia Bełchatów S.A.; Enion S.A. Obecnie cztery pierwsze firmy wchodzą w skład koncernu energetycznego PGE S.A.

Kluczową kategorią definiującą codzienną rzeczywistość społeczności zakładowej, relacje wewnętrzne oraz stosunki z otoczeniem zewnętrznym, jest pojęcie „wspólnoty”. Wspólnota w świadomości pracowników jest szczególnego typu systemem społecznym, tj. całością złożoną z kilku części: ze zbiorowości podstawowej, czyli pracowników danego przedsiębiorstwa (firmy); samej firmy jako pewnego bytu prawnego i ekonomicznego oraz zbiorowości rodzin pracowników, pośrednio, tj. poprzez danych pracowników, włączonych w krag wspólnoty.

Stosunek pracy, tzn. bycie pracownikiem firmy, jest warunkiem uczestnictwa we wspólnocie. Proces pracy ma określone znaczenie materialne, jako warunek egzystencji pracownika i jego rodziny. Jednakże z perspektywy wspólnotowej praca ma przede wszystkim charakter symboliczny: jest praktycznym wyrazem uczestnictwa we wspólnocie, wypełnieniem moralnego obowiązku wobec wspólnoty. Ścisły związek wspólnoty i pracy oraz symboliczny sens wykonywania pracy i bycia pracownikiem jest kluczem do zrozumienia sytuacji klas pracowniczych sektora publicznego, zwłaszcza w warunkach głębokich zmian strukturalnych. Relację pomiędzy pracownikami a pracodawcą czy właścicielem określa zasada dzielenia się dobrem w ramach wspólnoty. Zysk firmy to połączenie pracy szeregowego pracownika, wysiłku organizacyjnego menadżera oraz produktywności kapitału. Respektowanie zasady dzielenia się dobrem jest kryterium oceny pracodawcy/właściciela: albo jest on uznawany za część wspólnoty, albo za wyraziciela zewnętrznych sił i interesów.

Funkcja integracyjna wspólnoty dotyczy przede wszystkim uzgadniania interesów i unikania konfliktów. Dzięki tym dwóm procesom we wspólnocie występuje poczucie bliskości w kontaktach między ludźmi. Życie codzienne i praca splatają się ze soba, co daje poczucie bezpieczeństwa, wynikającego również z faktu poruszania się w znanym dobrze otoczeniu społecznym. Drugim aspektem integracji, jest traktowanie społeczności zakładowej jako części szerszej wspólnoty, zakorzenionej lokalnie, obejmującej więzi rodzinne i sąsiedzkie. Jest to zatem szczególny typ wspólnoty, która obejmuje niemal wszystkie przejawy aktywności życiowej swoich członków.

Związki zawodowe pełnią we wspólnocie rolę gwaranta ładu wewnętrznego. Działalność związków stabilizuje stosunki pracy, między innymi poprzez ograniczenie 
możliwości zmiany warunków pracy i płacy. Umowa społeczna jest elementem ładu wspólnotowego, który jest traktowany jako porządek nadrzędny wobec ładu administracyjnego czy rynkowego.

Silnym czynnikiem integracyjnym wspólnoty jest przewaga w świadomości badanych wartości typu kolektywistycznego nad wartościami indywidualistycznymi. Przykładem tego typu orientacji jest negatywne postrzeganie zjawiska rywalizacji pomiędzy menadżerami, które traktowane jest jako przejaw karierowiczostwa i tzw. wyścigu szczurów. Tego rodzaju postawy są oceniane negatywnie jako powodujące konflikty, a tym samym naruszające ład wspólnoty.

Warto zastanowić się, w jakim stopniu zaprezentowane prawidłowości, oparte na badaniach sprzed kilku lat, odpowiadają aktualnemu obrazowi społeczności bełchatowskich zakładowych elektrowni i kopalni. W okresie minionej dekady wiele czynników kształtujących sytuację tych środowisk uległo zmianie. Przede wszystkim spółki straciły osobowość prawną i zostały włączone do struktury organizacyjno-własnościowej PGE. Osłabiło to pozycję polityczną związków zawodowych, które straciły bezpośredni kontakt z pracodawca. Podmiotowość decyzyjna kadry dyrektorskiej uległa znacznemu ograniczeniu. Powstało też wiele firm zależnych, których związek ze wspólnotą zakładowa jest raczej luźny.

Moja wiedza ekspercka, wynikająca z nieformalnych kontaktów ze środowiskiem pracowniczym, pozwala sądzić, że wskazane procesy nie wpłynęły w istotny sposób na funkcjonowanie społecznych mechanizmów wewnątrz wspólnoty zakładowej. Formalne włączenie elektrowni i kopalni do hierarchicznej struktury koncernowej nie osłabiło więzi wspólnotowych. W świadomości pracowników centrala jest traktowana jako świat odległy, nieznany i trudny do zrozumienia.

Oczywiste jest, że funkcjonowanie w ramach tego typu wspólnoty zaspokaja potrzebę bezpieczeństwa pracowników. Informacje o zagrożeniu podstaw ekonomicznych tego systemu społecznego nie sa przyjmowane do wiadomości. Perspektywa lokalna może stać się elementem integrującym różne typy interesów, tym bardziej, że gra o kształt polskiej energetyki wciąż toczy się na poziomie instytucji państwa. W środowisku zawodowym energetyków w Bełchatowie wciąż silne jest przekonanie: „damy radę”. Równocześnie jednak wiele osób wśród młodszych wiekiem specjalistów i kierowników zaczyna analizować alternatywne scenariusze kariery zawodowej. 
Zarówno Bełchatów, jak i cała polska gospodarka stoją wobec zasadniczych wyzwań o charakterze systemowym. Nie ma jednak zgody, co do strategii umożliwiającej skuteczne przeprowadzenie transformacji energetycznej. Rozwiązania ewolucyjne, starające się zachować status quo, niosą ze sobą ryzyko przesunięcia Polski do sfery krajów peryferyjnych.

W tym kontekście warto przytoczyć receptę na transformację energetyki, sformułowaną przez Anthony Giddensa: „Musimy stworzyć taką przyszłość, w której odnawialne źródła energii zaspokoja większość zapotrzebowania. Będzie to niewątpliwie głęboka zmiana, o złożonych konsekwencjach ekonomicznych i społecznych. Współpracujcie z innymi krajami, regionami lub miastami intensywnie i stale, możliwie jak najszerzej w skali globu rozpowszechniając własne działania. Dodajcie do polityki odrobinę utopijnego myślenia. Dlaczego? Ponieważ bez względu na to, co się stanie, będziemy dążyć do takiej formy społeczeństwa, która w końcu okaże się zupełnie inna niż ta, w której obecnie żyjemy. Musimy zaryzykować, by osiagnąć nasze cele” [7, s. 21].

\section{Bibliografia}

[1] Ministerstwo Klimatu i Środowiska, 2021, Polityka Energetycžna Polski do 2040 r., Streszczenie, https://www.gov.pl/attachment/c5d4a303-2a45-4225-b84d-d6ad1 2f7c1c1 [27.01.2021]

[2] Wilczyński, M. 2019, Jaki wegiel dla Elektrowni Bekchatów? Zasoby i jakość wegla bru-

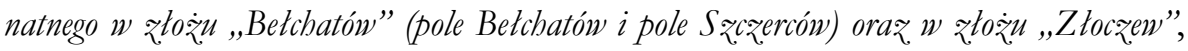
Fundacja ClientEarth Prawnicy dla Ziemi, Warszawa, https://www.documents.clientearth.org/download/16221/

[3] Pepliński, B. 2020, ŻYWNOŚĆ CZY WEGIEL. Wplyw kopalń na sektor rolno-sposyncsy w regionie Betchatowa, Ekspertyza, Uniwersytet Przyrodniczy w Poznaniu, Wydział Ekonomiczno-Społeczny, Poznań, https://www.researchgate.net/publication/347999816_ZYWNOSC_CZY_WEGIEL_Wplyw_kopaln_na_sektor_rolno-spozywczy_w_regionie_Belchatowa

[4] Gręda D., Kania K., Skomorowska K., Wiśniewski G., 2020, Miejsca pracy w fotowoltaice w latach 2020-2025, „Energia i Recykling” nr 5 
[5] Wiśniewski G., Michałowska-Knap K., Pandemia szansa dla OZE, 2020, „Rzeczpospolita" 30.04 .

[6] Oblicza polskiego konserwatyzmu. Wartości elit branżonych, 2010, (red.) Ruszkowski P., Wydawnictwo Naukowe UKSW, Warszawa.

[7] Giddens A., 2010, Katastrofa klimatyczna, Prószyński i S-ka, Warszawa 